\title{
Assessment of Best-Management Practice Effects on Rangeland Stream Water Quality Using Multivariate Statistical Techniques
}

\author{
Christopher A. Ellison, ${ }^{1}$ Quentin D. Skinner, ${ }^{2}$ and Larry S. Hicks ${ }^{3}$ \\ Authors are ${ }^{1} \mathrm{PhD}$, Rangeland Ecology and Watershed Management, PO Box 32224, Fridley, MN 55432, USA; ${ }^{2}$ Professor Emeritus, Renewable \\ Resources Department, University of Wyoming, Laramie, WY 82071, USA; and ${ }^{3}$ Natural Resource Coordinator, Little Snake River Conservation District, \\ Baggs, WY 82321, USA.
}

\begin{abstract}
Quantifying the effects of watershed improvement efforts is critical to agencies responsible for protecting water resources of the semiarid western United States. A complex water quality data set collected from 1994 to 2004 of upper Muddy Creek Basin was subjected to cluster analysis, discriminant analysis, and canonical correlation analysis to improve understanding of basin fluvial processes and to investigate whether livestock grazing best-management practices (BMPs) improved the water quality of the watershed. Hierarchical agglomerative cluster analysis grouped nine sampling sites into two clusters based on similarity of biological indices, separating the clusters into aquatic communities more and less tolerant of degraded stream conditions. Discriminant analysis yielded strong spatial and temporal distinctions, providing important data reduction by rendering seven key parameters (total dissolved solids [TDS], temperature, elevation, slope, 10-dominant taxa, percent collector-gatherers, and percent Plecoptera) for the spatial variation and four parameters (TDS, dissolved oxygen, total taxa, and community tolerance quotient) for the temporal variation. Canonical correlation analysis identified strong negative relationships among Plecoptera taxa and total taxa with TDS and turbidity in addition to strong positive associations with elevation, slope, and channel substrate weighted embeddedness value. Despite the onset of severe drought midway through the study period, overall reductions of $13 \%$ for TDS and a 30\% increase in macroinvertebrate total taxa occurred across years, strongly suggesting that improvements in water quality were correlated to BMPs that stabilized stream channels and improved the condition of riparian areas.
\end{abstract}

\section{Resumen}

La cuantificación del efecto de esfuerzos de mejoramiento de las cuencas hidrológicas es crítico para las agencias responsables de la protección de los recursos hídricos del oeste semiárido de los Estados Unidos. Un complejo base de datos de la calidad del agua de la parte superior de la Cuenca Muddy Creek Basín, colectados de 1994 a 2004, fue sujeto a un análisis de cuadrante, análisis discriminado y análisis de correlación, para mejorar el entendimiento del proceso fluvial de la cuenca, así como para investigar si las mejores prácticas de manejo (BMPs) del pastoreo del ganado, mejoran la calidad del agua de la cuenca. El análisis grupal jerárquico de aglomeración, agrupó nueve sitios de muestreo en dos cuadrantes, basados en la similitud de índices biológicos, separando los grupos dentro de comunidades acuáticas de mayor y menor tolerancia a las condiciones de degradación por la corriente. El análisis de discriminación produjo distinciones espaciales y temporales más fuertes, proporcionando importantes reducciones de datos por representación de siete parámetros claves (disolución de sólidos totales [TDS], temperatura, elevación, pendiente, porcentaje de las 10 dominantes taxa, porcentaje de colector-recolector y porcentaje de plecóptera) para la variación espacial, y cuatro parámetros (TDS, oxigeno disuelto, taxa total y cociente de tolerancia de la comunidad) para la variación temporal. El análisis canónico de correlación identificó una alta relación negativa entre taxa Plecoptera y taxa total, con TDS y turbidez, adicionalmente identificó una alta asociación positiva con elevación, pendiente y el recubrimiento del substrato del canal. A pesar del inicio de una severa sequía desde mediados hasta el final del periodo de estudio, ocurrió una reducción total de 13\% de TDS y un 30\% de incremento en la taxa total de invertebrados a lo largo de los años, sugiere que los mejoramientos en calidad del agua estuvieron correlacionados a las BMPs que estabilizaron los canales de la corriente y mejoraron la condición de las áreas ribereñas.

Key Words: discriminant analysis, drought, habitat degradation, impaired stream, macroinvertebrates, watershed

\section{INTRODUCTION}

Research was funded by the Little Snake River Conservation District, US Environmental Protection Agency and the University of Wyoming.

Mention of a proprietary product does not constitute a guarantee or warranty of the product by the Little Snake River Conservation District, the University of Wyoming, or the authors and does not imply its approval to the exclusion of other products that also may be suitable.

Correspondence: Christopher A. Ellison, PO Box 32224, Fridley, NM 55432, USA. Email: cellison57@gmail.com

Manuscript received 13 February 2008; manuscript accepted 25 April 2009
The linkage between livestock grazing and stream channel instability is complex. Myriad factors, such as watershed gradient, soil/geologic material, climate, upland and riparian plant communities, and land-use patterns, all interact to characterize the structure and function of a stream reach (Allan 1995) and may complicate the connection between grazing and channel condition. Streams respond differently to watershed disturbances, each exhibiting varying degrees of 
resiliency to differing grazing management strategies (Elmore and Kauffman 1994; Ohmart 1996). In any case, excessive grazing by livestock can degrade riparian areas by reducing riparian vegetation, cause channel aggradation or degradation, change stream-bank morphology, and may lower surrounding water tables (Platts 1986; Clary and Webster 1989).

In the early 1980s, the US Bureau of Land Management (BLM), landowners, and grazing permittees in Carbon County, Wyoming, recognized the need to counter deteriorated conditions in Muddy Creek Basin and began working toward improving the watershed. Historical overgrazing by livestock had resulted in widespread areas of unstable stream channels and loss of riparian function. Because of physical degradation of stream channels and riparian corridors, Muddy Creek, McKinney Creek, and Littlefield Creek in the upper basin were placed on the US Environmental Protection Agency's (USEPA's) 303(d) impaired stream list (Wyoming Department of Environmental Quality [WDEQ] 2006). In order to meet the legislative mandates of the Clean Water Act (CWA), the Little Snake River Conservation District (LSRCD) in Wyoming received \$774,000 of CWA Section 319 grant funding from 1992 to 2004, leveraging funds from other contributing entities and initiating best-management practices (BMPs) for Muddy Creek's watershed. To accomplish these efforts, LSRCD established a Coordinated Resource Management (CRM) process with the BLM, landowners, grazing permittees, Wyoming Game and Fish Department (WGFD), and other special-interest stakeholders.

Soon after funding became available, the LSRCD, landowners/permittees, BLM, and WGFD initiated numerous watershed improvement projects to stabilize stream channels, improve water quality, and rehabilitate riparian zones. The primary focus of BMPs was to address bank stability problems associated with riparian grazing and accelerated upland erosion related to season-long grazing practices. Planned grazing systems, cross fencing, off-stream water development, road and stream-crossing improvements, vegetation manipulation, and prescribed burns were implemented throughout the upper basin to achieve better distribution of livestock for both season and duration of use. Short-duration grazing rotation schemes and deferments until fall replaced continuous grazing on 280000 acres encompassing $112 \mathrm{~km}$ of perennial streams in 10 BLM grazing allotments. Landowners and grazing permittees ardently incorporated the new grazing strategies that they helped design during the CRM process. Deviations to implemented grazing strategies were uncommon except for a few localized regions where multiple changes in management had resulted in overutilization of riparian areas; elsewhere, deferred and short-duration grazing have been continuously practiced since 1992. Prescribed burning of over 6000 acres was conducted to reduce sagebrush and encourage establishment of desirable forage grasses, increase soil infiltrability, and reduce erosion. Over 20 permanent off-stream water supply sites, which included reservoirs, depression pits along roads, spring developments, and wells and pipelines, were constructed to attract livestock into upland areas where no previous grazing occurred because of unavailable water supplies. Fences and herding were also used to manage timing and frequency of use by livestock and to protect sensitive riparian areas.

Early in the project, funding was used exclusively to implement BMPs. Later, as more funding became available, water quality monitoring sites were established in the upper watershed to assess spatial and temporal variations in chemical, physical, and biological variables. Little by little from 1994 to 2000, nine monitoring sites were established. Macroinvertebrate sampling began at sites Doty Mountain, Bridger Pass, Littlefield, Grizzly, and Lake Draw in 1994. Two years later, in the fall of 1996, Lower McKinney site was established, and annual data collection (grab samples) for water quality parameters began at all six sites to coincide with macroinvertebrate sampling. In 2000, three additional monitoring sites were established at the McKinney Creek/Eagle Creek confluence, Little Muddy, and Upper McKinney. The gradual installation of monitoring sites, which commonly occurs in regionally led conservation projects, yielded fragmented data sets and complicated portions of the ensuing statistical analyses.

During inaugural BMP implementation years, stream channels stabilized, and riparian vegetation improved dramatically. Although quantitative data were not available to verify positive trends during the initial $3 \mathrm{yr}$ of the project, increased density and diversity of riparian vegetation, improved channel banks, and channel morphology suggest that water quality improved markedly. Auspiciously, the BLM had established permanent photopoints in the 1980s. These photopoints (Fig. 1) provide an ocular record of resource condition prior to BMP implementation and afford visual evidence that proved to be crucial in evaluating early BMP effects. Improvements in channel condition and riparian corridors, evident in pre- and post-BMP photographs, were combined with water quality trend analysis from 1995 to 1998 and resulted in the removal of Littlefield Creek and Muddy Creek in the Grizzly Allotment and McKinney Creek above Eagle Creek from table C of the 303(d) impaired stream list in 2000. Currently, there are two stream segments in the upper basin, Muddy Creek from Littlefield Creek to Alamosa Gulch and McKinney Creek below Eagle Creek (Fig. 2), that remain on the USEPA 303(d) impaired list because of habitat degradation (WDEQ 2006).

In this study, a complex water quality data set collected by the LSRCD and the BLM over an 11-yr period (1994-2004) using 21 variables at nine monitoring sites (2 415 observations) was subjected to hierarchical agglomerative cluster analysis (HACA), discriminant analysis (DA), and canonical correlation analysis (CCA) in order to improve understanding of upper basin fluvial processes and to investigate whether the numerous livestock grazing BMPs improved the water quality of the watershed. Univariate statistical $t$ test, analysis of stream cross sections, and analysis of variance (ANOVA) for precipitation amounts were conducted to lend additional support to multivariate data analyses results.

Specific analyses objectives were to 1) classify monitoring sites into distinct groups based on similarity of biological indices, 2) identify parameters responsible for spatial variation in the watershed, 3) describe parameters responsible for temporal variation during BMP implementation years, 4) develop and interpret parameter relationships, 5) characterize precipitation in the watershed, and 6) evaluate changes in channel morphology.

Research has shown that multivariate statistical techniques can be an effective tool to evaluate surface water quality and assist water resource protection efforts (St-Hilaire et al. 2004; Bishop et al. 2005; Santos et al. 2005; Singh et al. 2005; 


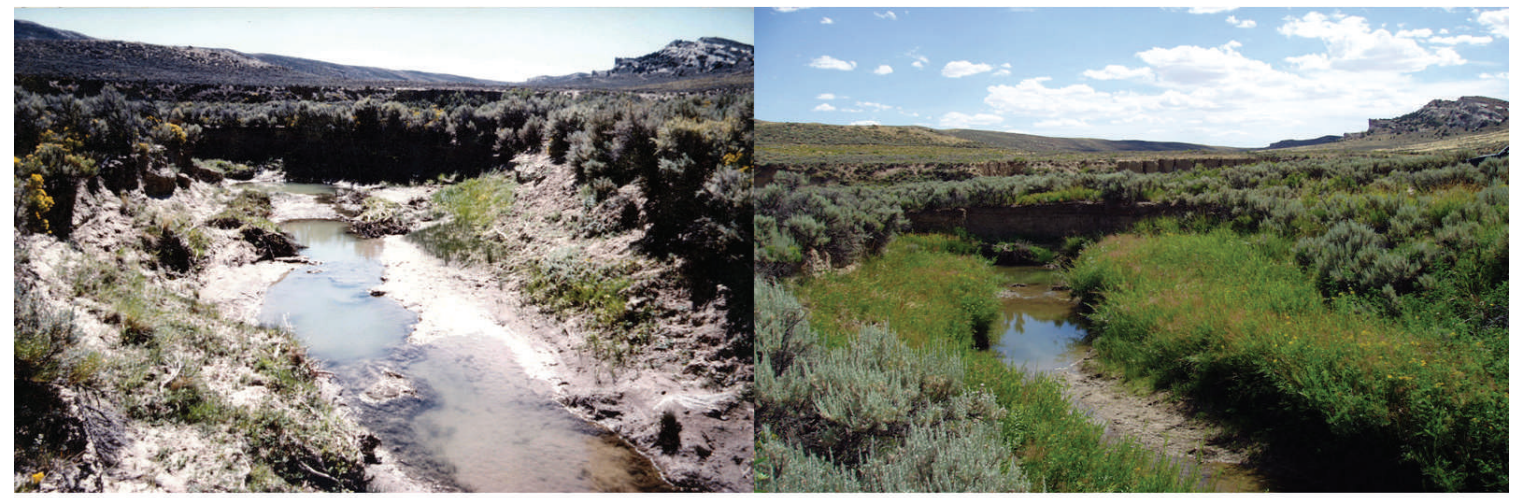

A.

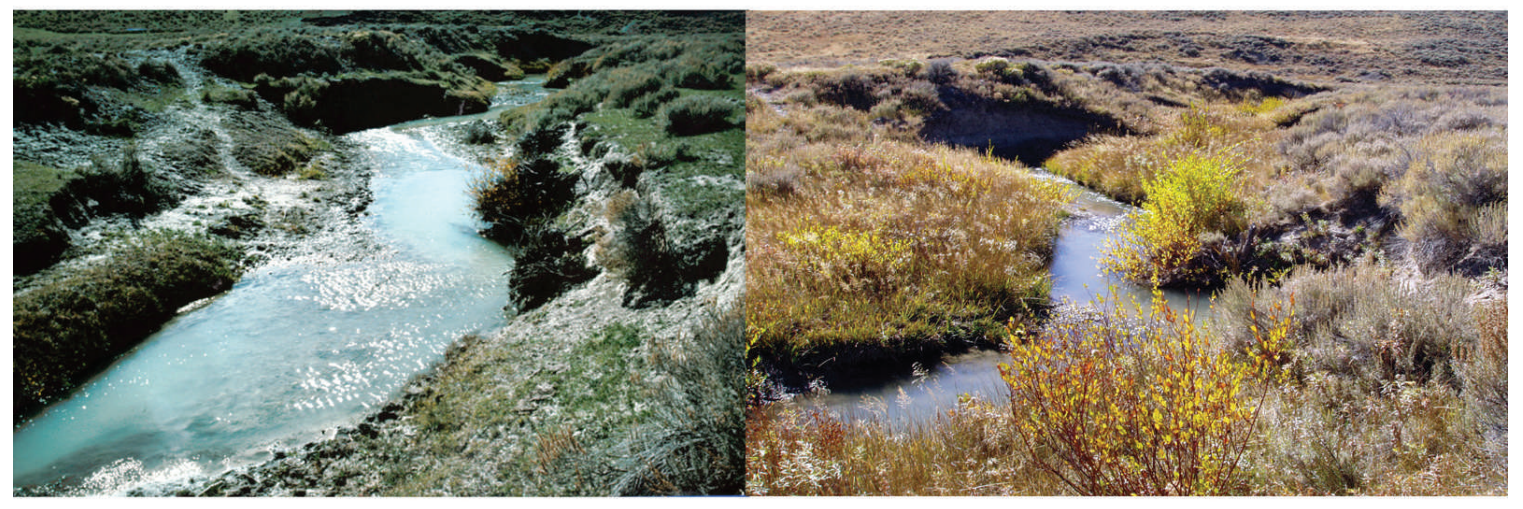

B.

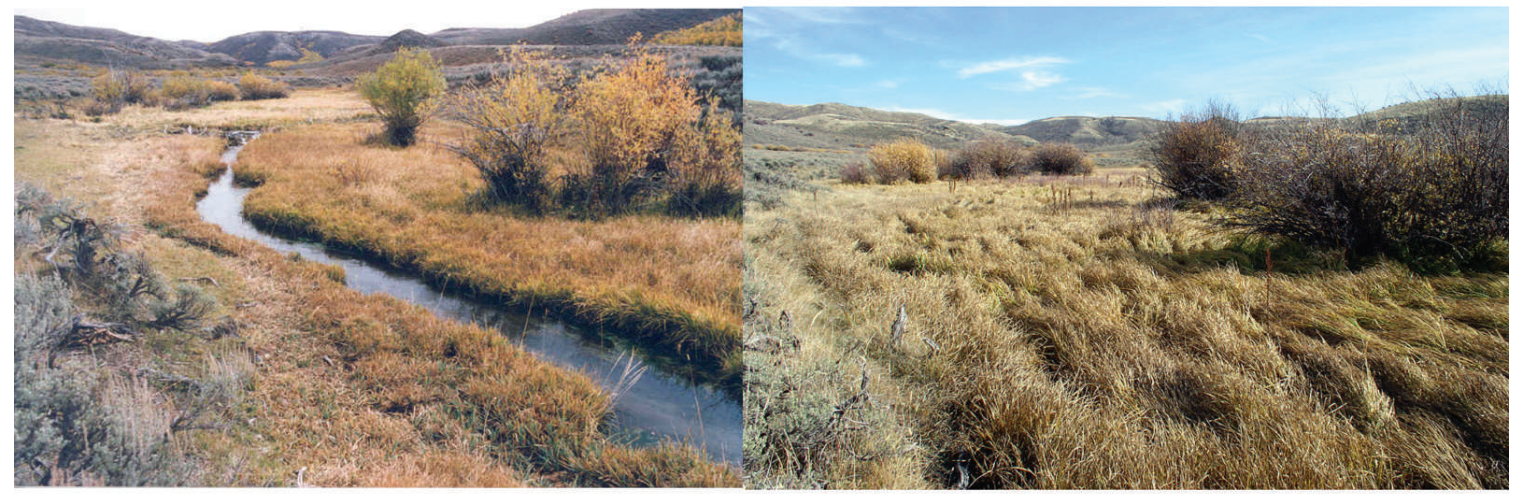

C.

Figure 1. Sample pre- and post-BMP implementation photopoints along Muddy Creek's main stem channel. A, Doty Mountain Allotment, 19892005; B, Sulfur Springs Allotment, 1989-2005; C, Grizzly Allotment, 1988-2005.

Shrestha and Kazama 2006; Heatherly and Whiles 2007; Zhou et al. 2007). The application of multivariate statistical techniques such as cluster analysis, DA, and CCA improves understanding of complex multivariable data sets by reducing data dimensionality, identifying parameters responsible for spatial and temporal variations, and evaluating variable relationships by assigning relative strengths to individual variables among large data sets (Klecka 1980; Thompson 1984; Hair et al. 1998).

\section{METHODS}

Muddy Creek watershed is located in south-central Wyoming in the upper Colorado River Basin. Muddy Creek originates at
$2400 \mathrm{~m}$ above mean sea level (amsl) along the western slope of the continental divide foothills along the northern flank of the Sierra Madre Mountains. The Sierra Madres are composed of Precambrian igneous and metamorphic rocks that are relatively resistant to erosion, whereas Muddy Creek and other nearby basin streams drain semiarid foothills that are composed of highly erosive sedimentary and marine shale deposits of primordial oceans (Swain 1957; Good 1960; Mears 1993; Steidtmann 1993). Muddy Creek, one of the larger intermittent streams in this semiarid landscape, flows $170 \mathrm{~km}$ to its confluence with the Little Snake River at $1920 \mathrm{~m}$ amsl. The Little Snake River flows into the Yampa River in northwest Colorado, which in turn joins the Green River, the largest tributary of the Colorado River near the Colorado/Utah 


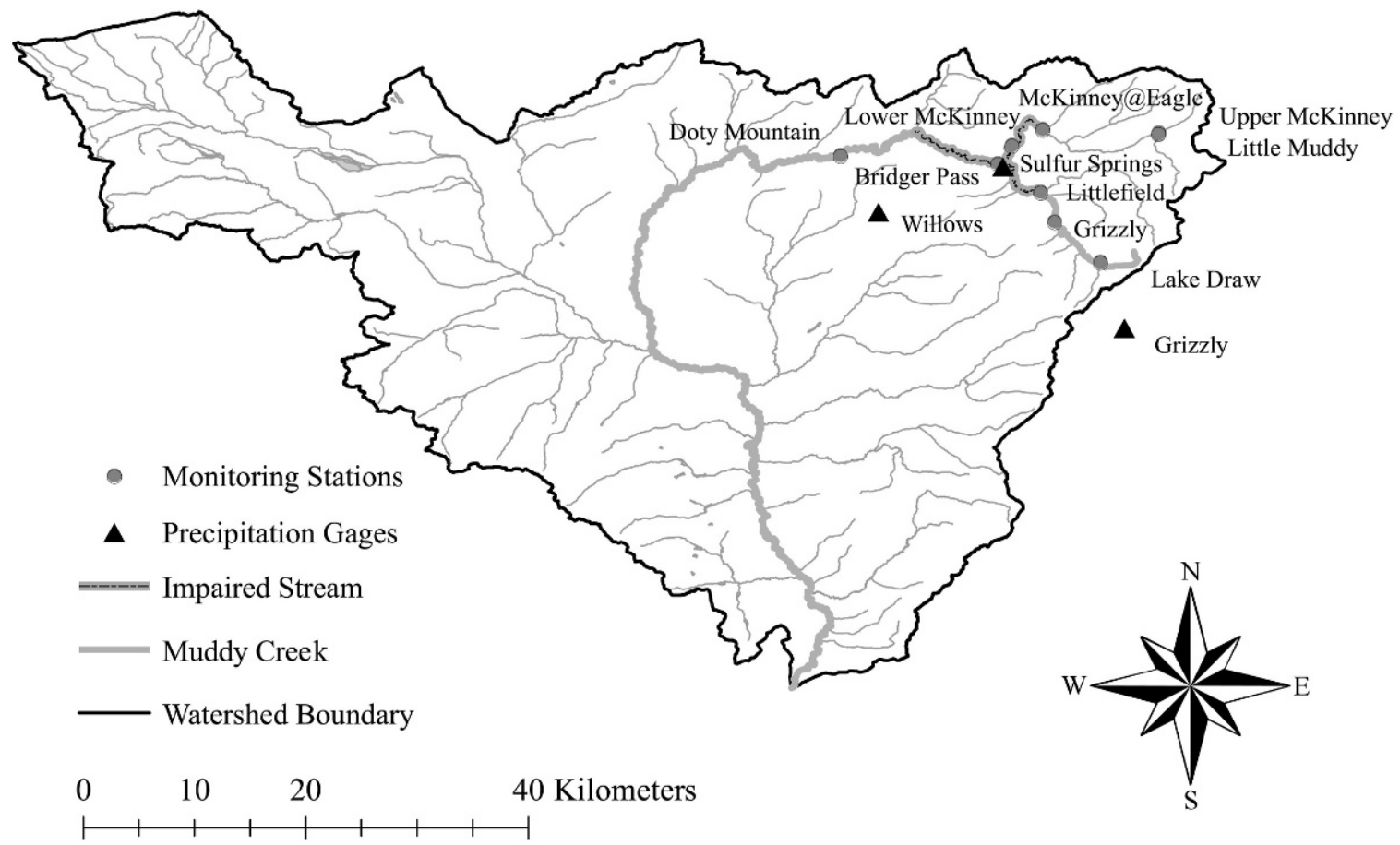

Figure 2. Muddy Creek Basin impaired streams, monitoring sites, and precipitation gauges.

border. The majority of the watershed $(69 \%)$ is public lands administered by the BLM, while $25 \%$ is privately owned, and $6 \%$ is state land (US Department of Agriculture [USDA] 1990). Other uses include oil and gas development, mining, recreation, and some irrigated hay production (Budd 1993). Watershed basin and stream characteristics are presented in Table 1.

Annual precipitation ranges from $200 \mathrm{~mm}$ in the western portion of the basin to $500 \mathrm{~mm}$ in the northeastern (headwaters) region. Spring through fall precipitation occurs as highintensity, short-duration thunderstorms. Hydrology is dominated by snowmelt during spring. Peak runoff, which occurs from April through June, approaches $36 \mathrm{~m}^{3} \cdot \mathrm{s}^{-1}$, whereas base flow rarely exceeds $0.3 \mathrm{~m}^{3} \cdot \mathrm{s}^{-1}$ (Goertler 1992). High-flow events occur sporadically in response to convective storms.

Table 1. Physical properties of Muddy Creek Basin and the main-stem channel, south-central Wyoming, 1994-2004.

\begin{tabular}{lc}
\hline Basin characteristics & Muddy Creek Watershed \\
\hline Total drainage area & $2470 \mathrm{~km}$ \\
Basin perimeter & $336 \mathrm{~km}$ \\
Main channel length & $170 \mathrm{~km}$ \\
Total stream length & $876 \mathrm{~km}$ \\
Total perennial stream length & $182 \mathrm{~km}$ \\
Number of first-order streams & $100^{1}$ \\
Highest stream order (Strahler) & 41 \\
Average stream slope & 0.0017 \\
Stream frequency & $0.19 \mathrm{stream} \cdot \mathrm{km}^{-21}$ \\
Drainage density & $0.35 \mathrm{~km} \cdot \mathrm{km}{ }^{-21}$ \\
Main channel sinuosity ratio & 1.74 \\
\hline
\end{tabular}

${ }^{1}$ Based on 1:100 000 scale map.

\section{Sampling}

Three aluminum cylinder $(8 \mathrm{~cm}$ width by $46 \mathrm{~cm}$ depth) rain gauges in the upper basin were used for the precipitation analysis. BLM personnel read precipitation totals four times annually on 15 April, 1 July, 1 September, and 15 October at sites Grizzly, Sulfur Springs, and Willows (Fig. 2). The years 1995 and 1996 were not used in the analysis because data were not collected at Sulfur Springs and Willows. Antifreeze and oil were added to the gauge cylinders to prevent freezing and evaporation of captured precipitation. In addition to the rain gages, nine water quality monitoring sites and 19 stream cross sections were established by the LSRCD and the BLM, respectively, in the upper watershed to evaluate spatial/ temporal variation in water quality and stream morphology. Macroinvertebrate sampling began in the fall of 1994, water quality parameter data collection began in the fall of 1996, and stream cross-section surveys were initially conducted to coincide with permanent photopoints in 1987.

Water Quality Parameters. Water quality parameters were collected annually at nine monitoring sites during the fall season from grab samples using a Hydrolab water quality sonde (Model H20, Hydrolab Corporation, Austin, TX). Water quality parameters consisted of $\mathrm{pH}$, specific conductance (EC), total dissolved solids (TDS), dissolved oxygen (DO), turbidity, and temperature. TDS was estimated using Equation 3, which was developed from grab samples collected at nine monitoring sites. According to Hanson et al. (1993), common relationships for estimating TDS from EC are

$$
\begin{aligned}
& \operatorname{TDS}\left(\mathrm{mg} \cdot \mathrm{L}^{-1}\right)=\mathrm{EC}\left(\mathrm{dS} \cdot \mathrm{m}^{-1}\right) \cdot 640 \quad(\text { if } \mathrm{EC}<5.0) \\
& \operatorname{TDS}\left(\mathrm{mg} \cdot \mathrm{L}^{-1}\right)=\mathrm{EC}\left(\mathrm{dS} \cdot \mathrm{m}^{-1}\right) \cdot 840 \quad(\text { if } \mathrm{EC} \geq 5.0)
\end{aligned}
$$


where TDS is total dissolved solids expressed in milligrams per liter $\left(\mathrm{mg} \cdot \mathrm{L}^{-1}\right)$, EC is electrical conductivity measured in decisiemens per meter $\left(\mathrm{dS} \cdot \mathrm{m}^{-1}\right)$, and the constants are regression coefficients (Hem 1970; Walling 1984; Hanson et al. 1993). Using available grab samples, Muddy Creek's relationship for estimating TDS from EC is

$$
\operatorname{TDS}\left(\mathrm{mg} \cdot \mathrm{L}^{-1}\right)=\mathrm{EC}\left(\mathrm{dS} \cdot \mathrm{m}^{-1}\right) \cdot 602
$$

with $F(33): 16823.42, P<0.001, R^{2}=0.996$, where $F(33)$ is the test statistic, 16823.42 is the result of dividing the variance within samples into the variance between samples, and (33) is the residual degrees of freedom.

Physical attributes consisted of elevation, slope, weighted mean substrate size (WMSS), weighted embeddedness (WEV), stream velocity, and stream flow. Elevations were obtained using a GPS receiver and verified from US Geological Survey 1:24000 scale maps. Slopes were calculated using ArcMap (Environmental Systems Research Institute 2006) digitized elevation maps. Substrate size and percentage embeddedness were estimated in the field from macroinvertebrate sampling quads following the WDEQ/Water Quality Division (WDEQ/ WQD 2004) Manual of Standard Operating Procedures for Sample Collection and Analysis. Water velocity was measured using a Swoffer electronic current meter (Model 2100; Swoffer Instruments, Inc., Seattle, WA). Velocities were obtained at equal increment measurements, and mean values were computed to obtain stream velocity at each site. Water velocity was multiplied by cross-sectional area to determine discharge rates using equal increment measurement and computation of stream flow procedures according to Rantz (1982).

Benthic macroinvertebrate samples were collected annually from August through November from 1994 to 2004. Late summer to fall sampling is designed to minimize year-to-year variability in macroinvertebrate populations resulting from natural climate variability. Additionally, habitat/substrate disturbance from natural causes is considered to be minimal during the late summer to fall time period (King 1993). At each site, eight-sample composites were collected from riffle locations using a $0.305-\mathrm{m}^{2}$ modified Surber sampler fitted with 500-micron netting. Macroinvertebrate samples were sent to the National Aquatic Monitoring Center, Department of Fisheries and Wildlife, Utah State University, in Logan, Utah, for organism identification. Insects were primarily identified to genus, with the exception of Chironomidae, which were identified to subfamily. Noninsect invertebrates were identified to various taxonomic levels depending on the availability of identification keys (National Aquatic Monitoring Center/ Department of Aquatic, Watershed, and Earth Resources 2003).

A total of 19 cross sections were surveyed pre- and post-BMP implementation to assess change in channel morphology. Cross sections were located in straight sections of the channel to minimize impact of lateral stream migration from high-flow events during spring snowmelt and convective storms. Steel posts were permanently anchored on both sides of the stream on the historic floodplain (second terrace level) to establish a reference datum (Andy Warren, BLM, personal communication, October 2007). Standard procedures for surveying stream cross sections were followed according to Harrelson et al. (1994).

\section{Analysis}

Discriminant and canonical correlation analyses were applied to raw data, whereas HACA was applied to data standardized through $z$-scale transformations in order to avoid misclassification due to differences in data dimensionality.

Precipitation relationships among seasons were developed using a one-way ANOVA, with Tukey's pairwise comparisons at a $95 \%$ confidence interval for an alpha level of 0.05 . Values were transformed if they failed the required statistical assumptions of equal variance and normal distributions of the residuals. The null hypothesis for the analysis was that mean precipitation among seasons were equal, and the alternate hypothesis was that at least two means among seasons were different. The hypothesis was tested for significance using transformed mean values when applicable. Winter precipitation comprised the 15 April readings, spring precipitation comprised the 1 July readings, summer precipitation comprised the 1 September readings, and fall precipitation comprised the 15 October readings.

Hierarchical agglomerative cluster analysis was conducted using Statistical Package for the Social Sciences (SPSS) software (SPSS 2005). Cluster analysis groups cases (i.e., monitoring sites) into classes on the basis of similarities within a class and dissimilarities between classes; hence, groups exhibit high internal (within-cluster) homogeneity and high external (between-cluster) heterogeneity. Biological indices were used to group sites because benthic macroinvertebrates integrate longterm cumulative impacts of degraded water quality and habitat in addition to incorporating the effects of short-term environmental variations (Vanotte et al. 1980; Metcalf 1989; Karr 1991). A total of 10 biological indices (total taxa, Ephemeroptera taxa, Plecoptera taxa, Tricoptera taxa, percent noninsects, community tolerance quotient [CTQa], percent collectorgatherers, percent Plecoptera, percent 10-dominant taxa, and scraper taxa) were used for the analysis. Using Ward's method (Hair et al. 1998), a dendrogram was developed to determine the number of clusters.

$\mathrm{DA}$ is a statistical technique that allows inspection of differences between two or more groups of objects with respect to several variables simultaneously. DAs were conducted to assess spatial and temporal variations among water quality, physical, and biological variables. If discriminating variables were detected, structure loadings and centroid values were used jointly to interpret the results. Structure coefficients (loadings) are product-moment correlations and determine the similarity between individual variables and the discriminating function (Klecka 1980; Hair et al. 1998). When the absolute magnitude of the loading is large (near +1.0 or -1.0 ), the function is carrying the same information as the individual variable. Variables with loadings exceeding an absolute value of 0.300 are considered to be significant discriminators between groups (Hair et al. 1998). Centroids are calculated to represent the group's mean on each of the variables (Klecka 1980). Because the centroid represents the position for its group relative to other groups, they infer information on how the groups differ (Klecka 1980; Hair et al. 1998). Classification analyses were performed post hoc in conjunction with DA to compute the proportion of correctly classified variables and to evaluate the effectiveness of discriminating variables. 
Table 2. Yearly precipitation totals and averages $(\mathrm{mm})$ of Muddy Creek Basin, south-central Wyoming, 1987-2006. ${ }^{1}$

\begin{tabular}{|c|c|c|c|c|c|}
\hline Year & Grizzly & Sulfur Springs & Willows & Yearly average & Departure from average \\
\hline 1987 & 332 & 310 & 293 & 311 & -43 \\
\hline 1988 & 330 & 294 & 268 & 298 & -56 \\
\hline 1989 & 291 & 304 & 306 & 300 & -54 \\
\hline 1990 & 327 & 305 & 234 & 289 & -65 \\
\hline 1991 & 356 & 369 & 307 & 344 & -10 \\
\hline 1992 & 389 & 363 & 337 & 363 & 9 \\
\hline 1993 & 599 & 564 & 544 & 569 & 215 \\
\hline 1994 & 325 & 292 & 273 & 297 & -57 \\
\hline 1997 & 558 & 487 & 447 & 497 & 143 \\
\hline 1998 & 434 & 403 & 416 & 418 & 64 \\
\hline 1999 & 490 & 408 & 357 & 418 & 64 \\
\hline 2000 & 364 & 297 & 191 & 284 & -70 \\
\hline 2001 & 318 & 275 & 290 & 294 & -60 \\
\hline 2002 & 259 & 195 & 197 & 217 & -137 \\
\hline 2003 & 328 & 313 & 340 & 327 & -27 \\
\hline 2004 & 376 & 367 & 331 & 358 & 4 \\
\hline 2005 & 480 & 394 & 335 & 403 & 49 \\
\hline 2006 & 447 & 407 & 315 & 390 & 36 \\
\hline Average & 389 & 353 & 321 & 354 & \\
\hline
\end{tabular}

${ }^{1}$ Data were not collected in 1995 and 1996.

For the spatial DA, a total of three functions (water quality, physical, and biological) were developed using 21 variables from nine monitoring sites. The stepwise procedure was incorporated, which accounts for multicollinearity by removing redundant variables during the analysis. Using SPSS software (SPSS Inc. 2005), Wilks's lambda $(\lambda)$ was used to test each of the null hypotheses that the data set(s) could not be used to differentiate between groups developed from HACA, whereas the alternate hypothesis was that data set(s) could be used to differentiate between groups. For each analysis, the chosen alpha value was 0.05 . Box's $M$ test was used to verify that the data set satisfied the statistical assumption for equality of variance/covariance matrices.

For the temporal DA, a total of three functions were developed using 21 variables from six monitoring sites. Little Muddy, McKinney/Eagle Creek, and Upper McKinney Creek were excluded from the temporal analysis to eliminate bias because they were established midway through the study period. Water quality parameters, biological indices, and physical attributes were separated into two year groups each to improve statistical power. Using SPSS software (SPSS 2005), Wilks's lambda $(\lambda)$ was used to test each null hypotheses that data set(s) could not be used to differentiate between year groups, whereas the alternate hypothesis was that data set(s) could be used to differentiate between year groups. For each analysis, the chosen alpha value was 0.05 .

CCA enables interpretation of complex relationships by accounting for multiple variable interrelationships. The CCA measures each variable's relative contribution to the relationship among multiple dependent variable relationships (Thompson 1984; Hair et al. 1998). Using Statistical Analysis Software (SAS; SAS Institute 2002), a total of three CCAs were conducted to develop the following relationships: 1) water quality parameters with physical attributes, 2) biological indices with water quality parameters, and 3) biological indices with physical attributes. If the data set(s) (canonical variates) were related, the strength of the relationship was evaluated via the canonical root (eigenvalues). Wilks's lambda $(\lambda)$ was used to assess significance, and canonical structure loadings were used to interpret the canonical variate's underlying structure.

Using SAS software (SAS Institute 2002), a total of 19 width/ depth (w/d) ratio relationships were developed between preand post-BMP implementation years using two-sample paired $t$ tests at a $90 \%$ confidence interval for an alpha value of 0.10. $\mathrm{w} / \mathrm{d}$ ratios failed the required statistical assumptions of equal variance and normal distributions of the residuals and were transformed using the natural log function. The null hypothesis for the analysis was that mean w/d ratios and maximum channel depths pre- and post-BMP implementation were equal, and the alternate hypothesis was that the means were different. The hypothesis was tested for significance using transformed mean values when applicable.

\section{RESULTS}

\section{Precipitation}

Yearly precipitation totals and averages for the upper watershed and individual rain gauges from 1987 to 2006 are presented in Table 2. Annual average precipitation ranged from $321 \mathrm{~mm}$ at Willows to $389 \mathrm{~mm}$ at Grizzly. The 20-yr annual precipitation average for the upper watershed was $354 \mathrm{~mm}$ using data from three BLM rain gauges.

Analysis of variance results indicated significant differences in precipitation totals among the four seasons with $F(206)$ : 46.72; $P<0.001$. Annual mean winter precipitation $(126 \mathrm{~mm})$ was significantly higher than spring $(67 \mathrm{~mm})$, summer $(44 \mathrm{~mm})$, and fall $(52 \mathrm{~mm})$ precipitation. Spring totals were significantly higher than summer with no difference detected when compared to fall amounts. No difference was detected 
Rescaled Distance Cluster Combine

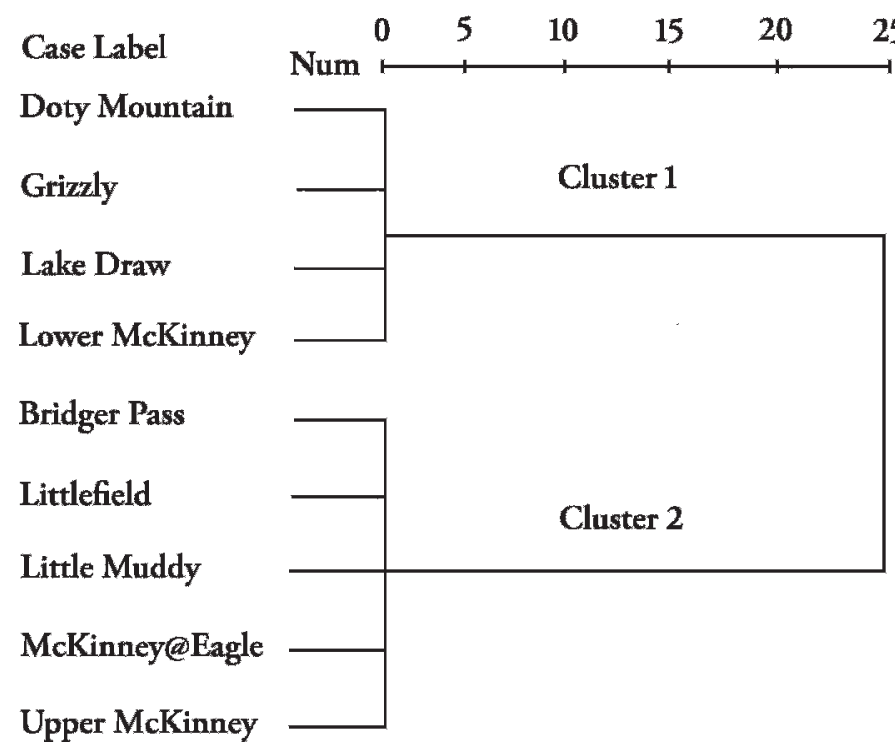

Figure 3. Dendrogram from hierarchical agglomerative cluster analysis, which grouped monitoring sites into two clusters based on 10 biological indices examined in this study. Samples arranged so that branches of dendrogram do not cross.

between summer and fall amounts. From 2000 to 2003, precipitation in the upper basin averaged $20 \%, 17 \%, 39 \%$, and $8 \%$, respectively, below the $20-y r$ mean annual amount of $354 \mathrm{~mm}$. Data from the three BLM rain gauges are consistent with precipitation amounts published by the Western Regional Climate Center (2008) and the North American Drought Monitor (NA-DM 2008), which reported a progressively worsening drought in Wyoming from 2000 to 2004.

\section{Hierarchical Agglomerative Cluster Analysis}

A total of 73 samples using 10 biological indices (730 observations) from nine monitoring sites yielded a dendrogram (Fig. 3) that rendered two clusters. Each cluster contains monitoring sites formed from similar benthic macroinvertebrate assemblages. Sites Doty Mountain, Grizzly, Lake Draw, and Lower McKinney constituted group 1, while group 2 was comprised of sites Bridger Pass, Littlefield, Little Muddy, McKinney/Eagle, and Upper McKinney.

\section{Spatial DA}

A total of 179 samples using 21 variables (1,321 observations) rendered three significant discriminating functions (water quality parameters, physical attributes, biological indices). Descriptive statistics for spatial variation of water quality and biological variables are presented in Table 3. Discriminant function test statistics, structure loadings, centroid values, and classification summaries are presented in Table 4.

Water quality parameter structure loadings indicated that TDS and temperature were significant discriminators between groups. Turbidity, DO, and $\mathrm{pH}$ were not used in the analysis because of multicollinearity identified from the incorporated stepwise procedure. Centroid values signify a moderate separation between group TDS concentrations and temperature. These data indicated that group 2 had lower TDS concentrations and higher temperatures when compared to group 1.

Physical attribute structure loadings identified slope and elevation as significant discriminators. WMSS and velocity had low structure loadings $(0.230$ and -0.123$)$ and yielded a small discriminating influence. Discharge and WEV were not used in the analysis because of multicollinearity. Centroid values denote a large separation between group slope and elevation, indicating that slope and elevation were significantly higher in group 2 when compared to group 1.

For biological indices, structure loadings identified percentages of 10-dominant taxa, collector-gatherers, and Plecoptera taxa as discriminating variables. Percentage (noninsects) had a low structure loading (0.002) and was not a significant discriminator. The remaining variables were not used in the analysis because of multicollinearity identified from the incorporated stepwise procedure. Centroid values indicated a significant separation among biological indices between the two groups. These data show that percent 10-dominant taxa and percent collector-gatherers were significantly higher in group 1 when compared to group 2, while percent Plecoptera taxa was significantly lower in group 1 .

\section{Temporal DA}

A total of 98 samples using 15 variables (765 observations) rendered two discriminating functions (water quality parameters and biological indices) for the temporal DA. Descriptive statistics for temporal variation of water quality and biological variables are presented in Table 5. Discriminant function test statistics, structure loadings, centroid values, and classification summaries for water quality and biological variables are presented in Table 6.

Water quality parameter structure loadings indicated that TDS and DO were significant discriminators between year groups. Temperature was not used in the analysis because of multicollinearity. Turbidity and $\mathrm{pH}$ were not significant discriminators because of low structure loadings. Centroid values denote a significant separation between year groups and indicated that TDS and DO concentrations were significantly lower in the final $3 \mathrm{yr}$ of the study.

Biological indices structure loadings identified CTQa as the dominant discriminator between year groups with significant although less discriminating influence from total taxa. Centroid values show that CTQa and total taxa were markedly higher during 2000-2004 when compared to initial years 1994-1999. The remaining eight biological indices were not used in the analysis because of multicollinearity identified from the incorporated stepwise procedure.

\section{CCA}

The CCA results are presented in Table 7. Wilks's lambda indicated significance for the first canonical function during each of the three analyses. These data indicated that water quality parameters were strongly related to physical attributes. TDS, elevation, and slope had large structure loadings, while turbidity and $\mathrm{pH}$ exhibited moderate loadings. The canonical root (eigenvalue/squared canonical correlation) demonstrated that $92 \%$ of the variance in water quality parameters was accounted for/shared by stream physical attributes and 


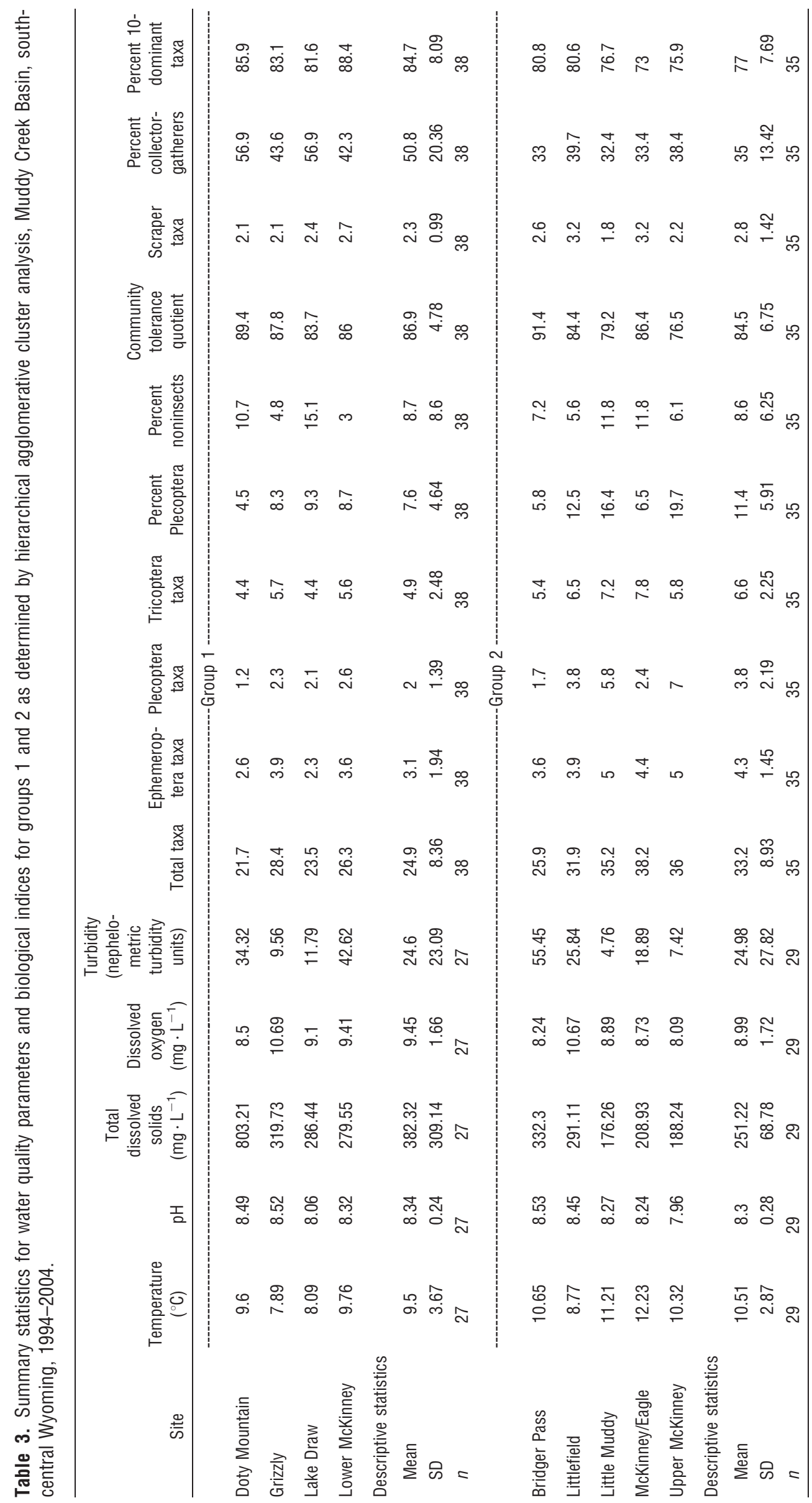




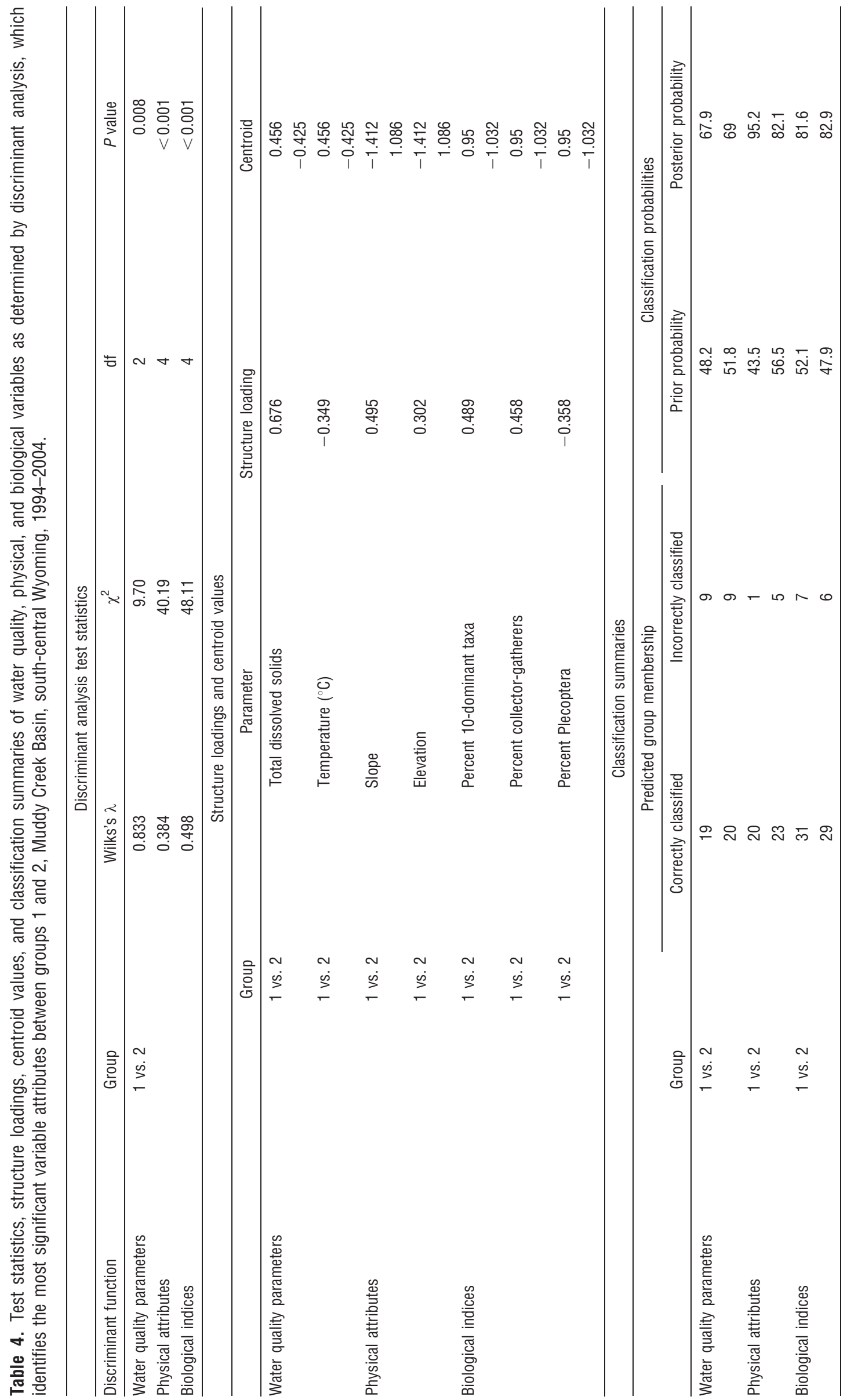




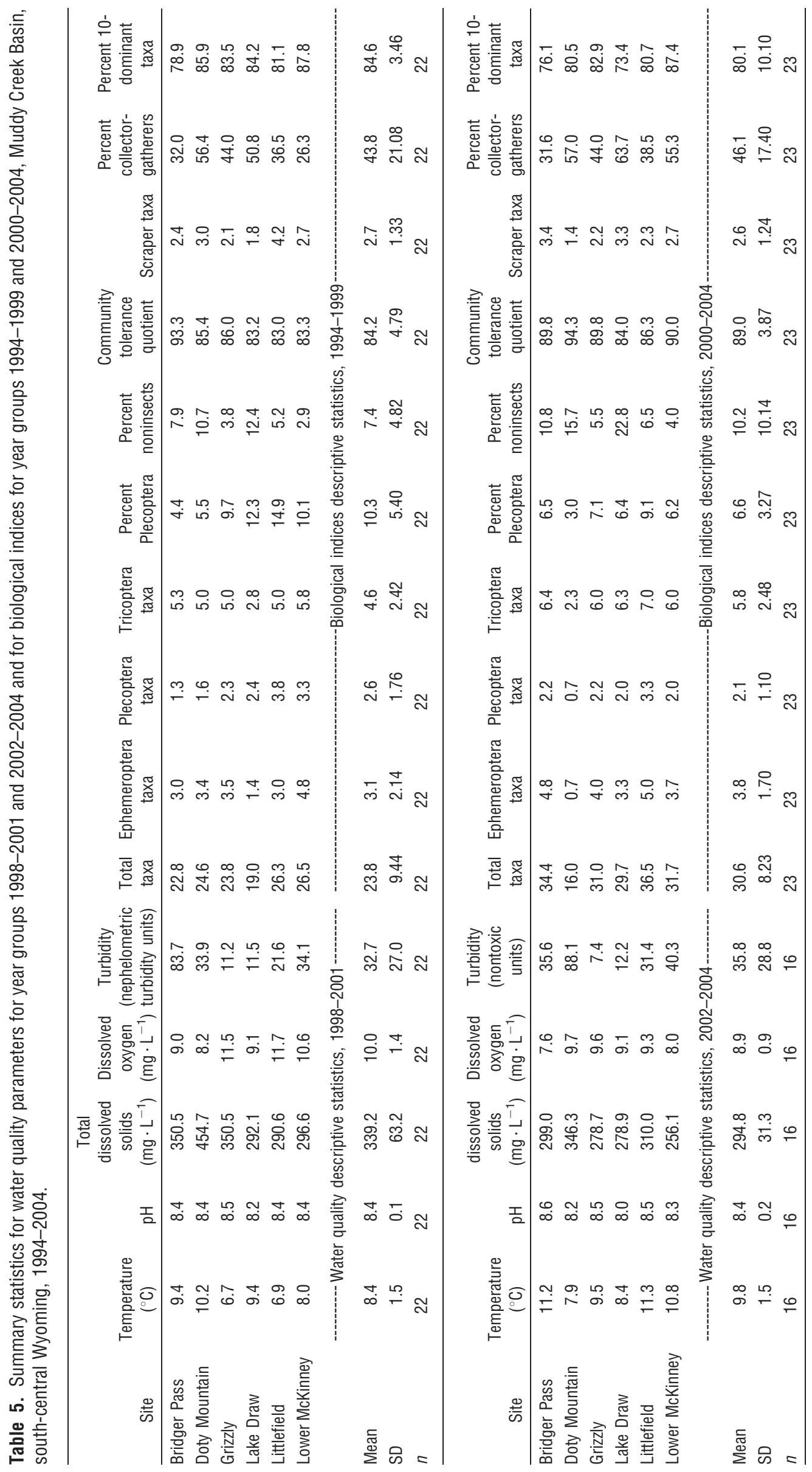


Table 6. Test statistics, structure loadings, centroid values, and classification summaries as determined by discriminant analysis, which identified the most significant variable attributes between year groups 1998-2001 and 2002-2004 for water quality parameters and between year groups 1994-1999 and 2000-2004 for biological indices, Muddy Creek Basin, south-central Wyoming, 1994-2004.

\begin{tabular}{|c|c|c|c|c|c|}
\hline Discriminant function & Year group & Wilks's $\lambda$ & $\chi^{2}$ & df & $P$ value \\
\hline Water quality parameters & $a^{1}$ vs. $b^{2}$ & 0.727 & 11.14 & 2 & 0.004 \\
\hline Biological indices & $c^{3}$ vs. $d^{4}$ & 0.441 & 33.96 & 3 & $<0.001$ \\
\hline \multicolumn{6}{|c|}{ Structure loadings and centroid values } \\
\hline Discriminant function & Year group & \multicolumn{2}{|c|}{ Parameter } & Structure loading & Centroid \\
\hline \multirow[t]{4}{*}{ Water quality parameters } & a vs. b & \multicolumn{2}{|c|}{ Total dissolved solids } & 0.716 & 0.508 \\
\hline & & & & & -0.699 \\
\hline & a vs. b & Dissolved ox & & 0.729 & 0.508 \\
\hline & & & & & -0.699 \\
\hline \multirow[t]{4}{*}{ Biological indices } & C vs. d & \multirow{2}{*}{\multicolumn{2}{|c|}{ Community tolerance quotient }} & 0.508 & -1.13 \\
\hline & & & & & 1.08 \\
\hline & c vs. d & \multirow{2}{*}{\multicolumn{2}{|c|}{ Total taxa }} & \multirow[t]{2}{*}{0.351} & -1.13 \\
\hline & & & & & 1.08 \\
\hline \multicolumn{6}{|c|}{ Classification summaries } \\
\hline & & \multicolumn{2}{|c|}{ Predicted group membership } & \multicolumn{2}{|c|}{ Classification probabilities } \\
\hline & Year group & Correctly classified & Incorrectly classified & Prior probability & Posterior probability \\
\hline \multirow[t]{2}{*}{ Water quality parameters } & a & 17 & 5 & 57.9 & 77.3 \\
\hline & $b$ & 11 & 5 & 42.1 & 68.8 \\
\hline \multirow[t]{2}{*}{ Biological indices } & c & 19 & 3 & 48.9 & 86.4 \\
\hline & d & 21 & 2 & 51.1 & 91.3 \\
\hline
\end{tabular}

\section{1998-2001.}

${ }^{2} 2002-2004$.

${ }^{3} 1994-1999$.

${ }^{4} 2000-2004$.

indicated a strong negative relationship between TDS and physical attributes' elevation and slope.

Biological indices demonstrated strong ties to water quality parameters. Plecoptera taxa, percent Plecoptera, CTQa, total taxa, and TDS had large structure loadings, while Tricoptera taxa, Ephemeroptera taxa, percent collector-gatherers, and turbidity exhibited significant yet moderate loadings. Large structure loadings among variables within the same canonical variate imply strong intervariate associations. For example, high structure loadings for Plecoptera taxa, percent Plecoptera, CTQa, and total taxa indicate that strong correlations exist among these variables. This was substantiated through DA, which excluded numerous variables from the spatial and temporal analyses because of multicollinearity detected during the stepwise procedure. The canonical root (eigenvalue) indicated that $62 \%$ of the variance in biological indices was accounted for/shared by water quality parameters and indicated a strong negative relationship between TDS and biological indices with the exception of CTQa and percent collectorgatherers, which had strong positive associations with TDS.

Biological indices also demonstrated strong relationships with stream physical attributes. Plecoptera taxa, CTQa, percent Plecoptera, and elevation had large structure loadings, while total taxa, slope, and WEV exhibited moderate loadings. The canonical root indicated that $80 \%$ of the variance in biological indices was accounted for/shared by physical attributes. These data indicated a strong negative correlation between CTQa and elevation along with a strong positive correlation between Plecoptera taxa and percent Plecoptera with elevation.
The complete analytical results comparing stream cross sections pre- and post-BMP implementation are presented in Table 8. These data demonstrated that mean w/d ratios decreased by 0.46 units and that mean depths increased by $0.22 \mathrm{~m}$ following BMP implementation.

\section{DISCUSSION}

\section{HACA}

The HACA was beneficial in delineating areas of relatively lower water quality and/or habitat. For these data, group 1 corresponds to benthic macroinvertebrate communities more tolerant of stressed conditions relative to group 2 communities. For example, group 1 sites contain lower numbers of sensitive taxa like Ephemeroptera, Plecoptera, and Tricoptera. Because benthic macroinvertebrate assemblages integrate environmental conditions, the two clusters indirectly represent heterogeneous stream habitat and/or water quality. Heatherly and Whiles (2007) used cluster analysis to group 53 streams in Illinois based on benthic macroinvertebrate taxa and attributed the distinctions among groups proportionately to differences in water quality and habitat condition. Generally, it is expected that water quality and/or habitat for sites constituting group 2 would be superior when compared to conditions at sites constituting group 1.

Thus, HACA was valuable by clustering monitoring sites into homogeneous groups and facilitated DA so that stream attributes responsible for spatial variation in the watershed 
Table 7. Test statistics and eigenvalues for canonical stream variates as determined by canonical correlation analysis, which identified the most significant relationships among water quality parameters, physical attributes, and biological indices, Muddy Creek Basin, south-central Wyoming, 1994-2004.

\begin{tabular}{|c|c|c|c|c|}
\hline Canonical variate & Wilks's $\lambda$ & $\mathrm{F}$ & $P$ value & Eigenvalue \\
\hline Water quality parameters vs. physical attributes & 0.0241 & 9.07 & $<0.001$ & 0.924 \\
\hline Biological indices vs. water quality parameters & 0.1166 & 2.25 & $<0.001$ & 0.624 \\
\hline Biological indices vs. physical attributes & 0.0374 & 3.42 & $<0.0001$ & 0.803 \\
\hline
\end{tabular}

Water quality parameters vs. physical attributes

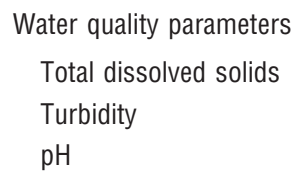

Physical attributes

Elevation

Slope

Biological indices vs. water quality parameters

$$
\begin{gathered}
\text { Structure loading } \\
-0.989 \\
-0.536 \\
-0.519
\end{gathered}
$$

0.920

0.798

$\begin{array}{lr}\text { Biological metrics } & 0.889 \\ \text { Plecoptera taxa } & 0.793 \\ \text { Percent Plecoptera } & -0.818 \\ \text { Community tolerance quotient } & 0.762 \\ \text { Total taxa } & 0.579 \\ \text { Tricoptera taxa } & 0.567 \\ \text { Ephemeroptera taxa } & -0.530 \\ \text { Percent collector-gatherers } & \\ \text { Water quality parameters } & -0.896 \\ \text { Total dissolved solids } & -0.403 \\ \text { Turbidity } & \\ \text { Biological indices vs. physical attributes } & -0.909 \\ \text { Biological metrics } & 0.892 \\ \text { Community tolerance quotient } & 0.874 \\ \text { Plecoptera taxa } & 0.516 \\ \text { Percent Plecoptera } & \\ \text { Total taxa } & \\ \text { Physical attributes } & 0.962 \\ \text { Elevation } & 0.516 \\ \text { Slope } & 0.503 \\ \text { Weighted embeddedness } & \end{array}$

could be identified. It is noteworthy that HACA assigned Lower McKinney into group 1, which was characterized by relatively more tolerant biological communities. Lower McKinney's assignation to group 1 is hypothesized to be the result of overutilization of riparian zones in this region from lapses in
BMP implementation strategy due to changes in livestock management (back to season-long use). This is supported by the assignations of Bridger Pass and McKinney/Eagle to group 2, even though both sites are located in close geographic proximity to Lower McKinney.

Table 8. Test statistics from $t$-test analysis comparing mean width/depth (w/d) ratios and stream channel depths prior to and following bestmanagement practices implementation, Muddy Creek Basin, south-central Wyoming, 1987-2005.

\begin{tabular}{lccccc}
\hline \multicolumn{1}{c}{ Treatment } & Mean & $n$ & $P$ value & $t$ statistic & 3.774 \\
\hline $1987-1988$ (w/d) & 6.791 & 19 & 0.0014 & 0.0973 \\
2005 (w/d) & 6.331 & 19 & & 0.0931 \\
$1987-1988$ (depth) & $3.808 \mathrm{~m}$ & 19 & 0.005 & -4.252 & 0.272 \\
2005 (depth) & $4.028 \mathrm{~m}$ & 19 & & 0.258 \\
\hline
\end{tabular}




\section{Spatial DA}

As streams flow through different types of terrain from headwaters to mouth, they exhibit certain characteristics that can generally be predicted based on climate, flow regime, substrate, gradient, and other landscape features (Vanotte et al. 1980). Generally, as elevation increases, watersheds become cooler and wetter, have steeper slopes, and are comprised of more weather-resistant parent material (Skinner 2003). These natural environmental attributes typically equate to lower elemental concentrations and thus lower TDS concentrations as elevation increases. For instance, Vitousek (1977) studied 57 watersheds in the northeastern United States and reported significantly lower concentrations of $\mathrm{Cl}^{-}, \mathrm{SO}_{4}^{2-}, \mathrm{Na}^{+}, \mathrm{Ca}^{2+}$, and $\mathrm{Mg}^{2+}$ as elevation increased, attributing the spatial variation along the elevation gradient to differences in rock weathering and evapotranspiration rates.

Accordingly, these data show that spatial variation in TDS concentrations between groups 1 and 2 may in part be attributed to innate differences in elevation. Deviations from incorporated modifications to historic livestock grazing practices also may help explain spatial variation for TDS in the upper watershed. Grazing practices at group 1 sites included predominantly high-intensity, low-frequency grazing during summer months, while group 2 sites used alternate year spring/fall rotation schemes or deferred grazing until fall (Andy Warren, BLM, personal communication, December 2007). Research shows that avoiding grazing in riparian zones during summer is critical because livestock are much less likely to disperse across grazing allotments during the hot portion of the growing season (Myers 1989) when they may damage riparian areas by channel degradation and lowering of the water table (Platts and Raleigh 1984). Although deferredrotation grazing has been implemented throughout the upper basin, occasional departures from planned grazing strategies occurred. As stated earlier, Lower McKinney Creek experienced changes in grazing management back to extended summer use during the study period. Thus, lapses in grazing management strategies resulted in overgrazing of livestock along stream channels that resulted in Lower McKinney improvements lagging behind other areas. A similar phenomenon was observed at Bridger Pass monitoring site in 2001, which is located in the same pasture as the Lower McKinney Creek site, where markedly higher turbidity values were observed during the fall season. Amplified turbidity values coincided with livestock being allowed continuous access to riparian areas from midsummer through the fall season (Larry Hicks and Jay Sheehan, LSRCD natural resource coordinator and resource technician, respectively, personal communication, August 2008).

Higher stream temperatures observed in group 2 are counterintuitive because heat can adversely affect aquatic life. Distinctively higher stream temperatures may in part be attributed to the onset of drought during the study period. According to the NA-DM (2008) and National Oceanic and Atmospheric Administration (2007), Muddy Creek Basin experienced extreme drought from 2000 to 2003. The comparatively higher mean temperatures for group 2 likely resulted from establishing monitoring sites Little Muddy, Upper McKinney, and McKinney/Eagle midway through the study period, which coincided with the onset of drought. These sites contribute important information that helps explain spatial variation for water quality and aquatic health in the watershed; however, temperature data at these sites appear to be biased because of drought effects. It is expected that if stream temperatures were collected at these sites prior to drought, the resultant moderating effect may have eliminated the observed difference in temperature between the two groups.

These data show significant spatial variation in biological indices with higher percents of Plecoptera, 10-dominant taxa, and collector-gatherers observed in group 1 when compared to group 2. Percents of Plecoptera, 10-dominant taxa, and collector-gatherers describe various elements of the biological community. The 10-dominant taxa percentage is used as an indicator of degraded conditions because the dominance of a few taxa is often related to physical and chemical conditions that benefit a few organisms (Barbour et al. 1999). Collectorgatherers feed primarily on or within fine sediments; thus, the dominance of collector-gatherers in a community is associated with increased sediment (Merritt and Cummins 1996). Likewise, Plecoptera are sensitive to pollution and disturbances; thus, a low percent Plecoptera implies stressed conditions.

Spatial variation in density and diversity of macroinvertebrate assemblages may be attributed to observed differences in water quality between the two groups, which may be attributed to differences in elevation along with intermittent spatial and temporal deviations in planned grazing implementation strategies. Additionally, latent differences between group WMSS and WEV may have contributed to significant distinctions between group benthic macroinvertebrate assemblages. Research shows that benthic macroinvertebrate density and diversity decreases with smaller substrate sizes and increased substrate embeddedness (Sandine 1974; Quinn and Hickey 1990).

In summary, spatial DA reduced data dimensionality and provided important clues that helped improve understanding of the upper watershed's water quality. Elevation and slope, which were significantly different between the two groups, are innate geographical features not likely to change over short time periods, yet they impart site-specific influence on water quality. Moreover, these data suggest that stream habitat can be improved by lowering TDS concentrations and temperature through efforts to increase riparian vegetation and stream canopy cover and by stabilizing banks through effective BMP implementation strategies. Post hoc classification analysis substantiated the usefulness of DA by verifying that discriminating variables afforded over $80 \%$ correct assignations to groups. Classification analysis is beneficial because it evaluates the accuracy of DA to predict group assignments. For example, the random chance of predicting group assignations was $48 \%$ $(35 / 73)$ prior to accomplishing the DA (Table 4). Because the DA correctly assigned 29 of 35 biological samples to group 2, the probability increased to $83 \%$, a substantial improvement.

\section{Temporal DA}

Mixed results in temporal DA suggested that drought conditions affected water quality and ecological condition and complicated the analyses by partially obscuring positive BMPs effects. For instance, DO concentrations, which declined during the last $3 \mathrm{yr}$ of the study period, can be attributed to higher stream temperatures that likely resulted because of extended drought. Higher temperatures and corresponding lower DO concentrations would be expected to cause a shift in the community to 
more tolerant species (Cazaubon and Giudicelli 1999). Nonetheless, positive trends in water quality were anticipated from the incorporated BMPs. For example, these data demonstrated a $13 \%$ reduction in TDS concentrations even though drought persisted through the study period. This is important because sediment yield, which is the primary transport mechanism for nonpoint-source pollutants (USDA 1985), was hypothesized to be maximized during the drought period following Langbein and Schumm's (1958) study that documented that highest sediment yields occur at an effective annual precipitation of around $300 \mathrm{~mm}$ (consistent with amounts observed in upper Muddy Creek basin). Moreover, significant reductions in TDS occurred contrary to flow dilution relationships widely observed between TDS and stream flow, which typically demonstrates increases in TDS concentrations as stream flow decreases (Allan 1995; Colorado River Basic Salinity Control Forum 2005). For this study, the observed reduction in TDS during decreased stream flow is not attributable to lower precipitation rates since the annual mean value of $280 \mathrm{~mm}$ is expected to increase sediment yields. Improved riparian areas appear to be enhancing the watershed's nonpoint-source buffering capacity, which likely mitigated some of the drought effects and contributed to the positive trends observed in TDS.

Despite the onset of drought, numerous biological indices improved during the study period, also suggesting that BMPs countered some of the adverse impacts of drought. For example, significant increases in total taxon indicated an increase in overall taxonomic variety. Although not statistically different, subtle increases in raw mean Ephemeroptera and Trichoptera taxa, a decrease in percent 10-dominant taxa, and a decrease in percent collector-gatherers imply positive trends in ecological condition. Conversely, significant increases in CTQa along with decreases in Plecoptera taxa and percent Plecoptera taxa and increases in percent noninsects suggest stressed conditions during the final years of the study period.

The CTQa is an index that designates a numerical tolerance quotient to benthic macroinvertebrates. A pollution-sensitive benthic macroinvertebrate, such as Ephemeroptera, will have a low CTQa numeric rating (Merritt and Cummins 1996). Significantly higher CTQa values during 2000-2004 may be attributed to decreases in velocity, depth, and wetted width with the onset of lower flows (Zoë et al. 2007). The loss of wetted width reduces available biotic habitat (Cowx et al. 1984; Stanley et al. 1997), lowers habitat diversity (Cazaubon and Giudicelli 1999), and alters habitat suitability (Cowx et al. 1984). Additionally, water temperature tends to increase during periods of low flow (Rader and Belish 1999), further exacerbating drought effects because of corresponding decreases in dissolved oxygen content. Low or reduced flows in perennial streams often cause decreases in taxonomic richness (Cazaubon and Giudicelli 1999), and gradual changes to the macroinvertebrate community occur from the ensuing altered habitat. Wood et al. (2000) reported that taxa with preferences for low water velocities and fine sediments characterized sites during drought years and that taxa with preferences for high velocities and gravel substrate occupied sites during nondrought years. Thus, the onset of drought is hypothesized to have altered stream habitat and shifted the macroinvertebrate community to one comprised of aquatic insects with higher tolerance values.

\section{CCA}

The CCA corroborates spatial and temporal DA for this watershed and follows research that documented Ephemeroptera and Tricoptera taxa sensitivities to elevated TDS and turbidity. For example, Goetsch and Palmer (1997) observed that certain mayfly and caddis fly species decreased in response to increased TDS and $\mathrm{SO}_{4}^{2-}$ concentrations. Winget and Mangum (1979) also reported a negative association between total taxa and $\mathrm{SO}_{4}^{2-}$ concentrations in western United States streams. In addition to impacts from elevated TDS concentrations, high turbidity potentially changes macroinvertebrate community structure by preventing sunlight penetration, thereby reducing photosynthesis by algae and periphyton. Elevated turbidity is generally associated with amplified levels of suspended sediment that tend to settle in the channel bed during periods of low flow. Excessive sediment deposition may reduce density and diversity of macroinvertebrates by smothering, reduction in exposed habitat or colonization, and reduction in stable streambed habitat (King 1993). Weigel (2003) used CCA to correlate environmental conditions like riparian condition, habitat heterogeneity, and streambed and stream-bank condition with macroinvertebrate metrics in order to quantify human influence on watersheds in three ecoregions in Wisconsin. Using CCA, he reported strong correlation values among environmental variables with species richness and Epemeroptera-Plecoptera-Tricoptera taxa.

Thus, CCA was important in identifying the strongest relationships among parameters and improved understanding of Muddy Creek's watershed water quality and ecological condition. Additionally, these results corroborate findings from spatial and temporal DA and offer strong evidence that BMPs designed to lower TDS concentrations and turbidity will improve biological condition.

\section{Stream Cross Sections}

Cross-section data provide valuable information related to how changes in riparian zone condition and grazing management influence channel morphology. These data demonstrated positive trends in w/d ratios and stream depths following BMP implementation. Reducing w/d ratios and increasing stream depth is desirable because a narrower, deeper channel has less friction and promotes increased stream flow velocity. Increased velocity helps flush fine sediment and keeps stream channel substrates free from finer sediments, which are considered detrimental to aquatic life (Allan 1995; King 1993). It is hypothesized that the narrowing and deepening of the channel resulted from mobilized sediments from the stream bottom that were subsequently trapped and stabilized on stream banks by riparian zone vegetation that had improved in both density and diversity following BMP implementation.

\section{MANAGEMENT IMPLICATIONS}

Multivariate statistical techniques of HACA, DA, and CCA improved understanding of upper basin fluvial processes and afforded insight on best-management practice effects on surface water quality. The HACA provided meaningful diagnostic 
information by delineating areas of relatively lower water quality and/or habitat, while DA provided important data reduction by identifying seven discerning parameters for spatial variation and four key parameters for temporal variation. Temporal DA identified positive trends in TDS and total taxa during the study period despite the onset of drought, suggesting that improved riparian zones, channel morphology, and stabilized stream banks from incorporated BMPs enhanced the nonpoint buffering capacity in the upper watershed. CCA improved understanding of watershed processes by detecting numerous strong relationships among watershed parameters, yielding insight and offering evidence that management practices designed to lower TDS will propagate corresponding increases in density and diversity of benthic macroinvertebrate communities.

\section{LITERATURE CITED}

Allan, J. D. 1995. Stream ecology: structure and function of running waters. London, United Kingdom: Chapman \& Hall Publishing. 388 p.

Barbour, M. T., J. Gerritsen, B. D. Snyder, and J. B. Stribbling. 1999. Rapid bioassessment protocols for use in streams and wadeable rivers: periphyton, benthic macroinvertebrates, and fish. 2nd ed. EPA 841-B-99002. Washington, DC, USA: US Environmental Protection Agency, Office of Water. 339 p.

Bishop, P. L., W. D. Hively, J. R. Stedinger, M. R. Rafferty, J. L. Lojpersberger, and J. A. BLOomfield. 2005. Multivariate analysis of paired watershed data to evaluate agricultural best management practice effects on stream water phosphorus. Journal of Environmental Quality 34:1087-1101.

Budd, R. W. 1993. A Wyoming stream's riparian zone response to instream structures [thesis]. Laramie, WY, USA: University of Wyoming. $72 \mathrm{p}$.

Cazaubon, A., and J. Giudicelli. 1999. Impact of the residual flow on the physical characteristics and benthic community (algae, invertebrates) of a regulated Mediterranean river: the Durance, France. Regulated Rivers: Research and Management 15:441-461.

ClaRy, W. P., and B. F. WebSter. 1989. Managing grazing of riparian areas in the intermountain region. Ogden, UT, USA: US Department of Agriculture Forest Service General Technical Report INT-263. 15 p.

Colorado River Basin Salinity Control Forum. 2005. 2005 review. Water quality standards for salinity Colorado River system. Bountiful, UT, USA: CRBSCF. $80 \mathrm{p}$.

Cowx, I. G., W. O. Young, and J. M. Hellawell. 1984. The influence of drought on the fish and invertebrate populations of an upland stream in Wales. Freshwater Biology 14:165-177.

Elmore, W., AND J. B. Kauffman. 1994. Riparian and watershed systems, degradation and restoration. In: M. Vavra, W. A. Laycock, and R. D. Pieper [EDS.]. Ecological implications of livestock herbivory in the West. Denver, CO, USA: Society for Range Management. p. 212-232.

Environmental Systems Research Institute. 2006. ArcMap version 9.2. Redlands, CA, USA: ESRI.

Goertler, C. M. 1992. Sediment dynamics within channel and riparian zone types along a cold-desert Wyoming stream [thesis]. Laramie, WY, USA: University of Wyoming. $205 p$.

Goetsch, P., And C. G. Palmer. 1997. Salinity tolerances of selected macroinvertebrates of the Sabie River, Kruger National Park, South Africa. Archives of Environmental Contamination and Toxicology 32:32-41.

Good, L. W. 1960. Geology of the Baggs area, Carbon County, Wyoming [thesis]. Laramie, WY, USA: University of Wyoming. $90 \mathrm{p}$.

Hair, J. F., R. E. Anderson, R. L. Tatham, and W. C. Black. 1998. Multivariate data analysis. 5th ed. Englewood, Cliffs, NJ, USA: Prentice Hall. 730 p.

Hanson, B., S. R. Grattan, and A. Fulton. 1993. Agricultural salinity and drainage: a handbook for water managers. Davis, CA, USA: University of California Irrigation Program, University of California, Davis. $156 \mathrm{p}$.
Harrelson, C. C., C. L. Rawlins, and J. P. Potyondy. 1994. Stream channel reference sites: an illustrated guide to field technique. Fort Collins, CO, USA: US Department of Agriculture, Forest Service, Rocky Mountain Forest and Range Experiment Station, General Technical Report RM-245. 61 p.

HeATHERLy, T., AND M. R. Whiles. 2007. Relationships between water quality, habitat quality, and macroinvertebrate assemblages in Illinois streams. Journal of Environmental Quality 36:1653-1660.

Hem, J. D. 1970. Study and interpretation of the chemical characteristics of natural water. 2nd ed. US Geological Survey Water Supply Paper 1473. Washington, DC, USA: US Government Printing Office. 263 p.

KARR, J. R. 1991. Biological integrity: a long-neglected aspect of water resource management. Ecological Applications 1:66-84.

KING, K. W. 1993. A bioassessment method for use in Wyoming stream and river water quality monitoring. Cheyenne, WY, USA: Wyoming Department of Environmental Quality. $84 \mathrm{p}$.

KLECKA, W. R. 1980. Discriminant analysis. Sage University paper series on quantitative application in the social sciences, 07-019. Beverly Hills, CA, USA: Sage Publications. 72 p.

Langbein, W. B., And S. A. Schumm. 1958. Yield of sediment in relation to mean annual precipitation. Transactions American Geophysical Union 39:1076-1084.

Mears, B., JR. 1993. Geomorphic history of Wyoming and high-level erosion surfaces. In: A. W. Snoke, J. R. Steidtmann, and S. M. Roberts [EDs.]. Geology of Wyoming: geological survey of Wyoming memoir 5. Laramie, WY, USA: Geological Survey of Wyoming. p. 608-626.

MerRitt, R. W., and K. W. Cummins. 1996. An introduction to the aquatic insects of North America. 3rd ed. Dubuque, IA, USA: Kendall/Hunt Publishing. 862 p.

MetCALF, J. L. 1989. Biological water quality assessment of running waters based on macroinvertebrate communities: history and present status in Europe. Environmental Pollution 60:101-139.

MYeRs, L. H. 1989. Grazing and riparian management in southwestern Montana. In: R. E. Gresswell, B. A. Barton, and J. L. Kershner [eds.]. Practical approaches to riparian resource management: an education workshop; 8-11 May 1989. Billings, MT, USA: US Department of the Interior, Bureau of Land Management. p. 117-120.

[NA-DM] North American Drought Monitor. 2008. U.S. Drought Monitor archives. Available at: http://www.drought.unl.edu/dm/archive.html. Accessed 16 0ctober 2008.

National Aquatic Monitoring Center/Department of Aquatic, Watershed, and Earth REsources. 2003. Aquatic macroinvertebrate monitoring report. Logan, UT, USA: Utah State University. $31 \mathrm{p}$.

National Oceanic and Atmospheric Administration. 2007. Drought information center. Available at: http://www.drought.noaa.gov. Accessed 31 December 2007.

ОнмаRт, R. 1996. Historical and present impact of livestock grazing on fish and wildlife resources in western riparian habitats. In: P. Krausman [ED.]. Rangeland wildlife. Denver, CO, USA: Society for Range Management. $p$. 245-279.

PLATTS, W. S. 1986. Riparian-stream management. In: National range conference proceeding; 6-8 November 1985; Oklahoma City, OK, USA. Washington, DC, USA: US Department of Agriculture. p. 70-74.

Platts, W. S., and R. F. Raleigh. 1984. Impacts of grazing on wetlands and riparian habitat. In: Developing strategies for rangeland management. Boulder, CO, USA: Westview Press. p. 1105-1117.

Quinn, J. M., AND C. W. Hickey. 1990. Magnitude of effects of substrate particle size, recent flooding, and catchment development on benthic invertebrates in 88 New Zealand rivers. New Zealand Journal of Marine and Freshwater Research 24:411-427.

RadeR, R. B., AND T. A. BelISH. 1999. Influence of mild to severe flow alterations on invertebrates in three mountain streams. Regulated Rivers: Research and Management 15:353-363.

Rantz, S. E. 1982. Measurement and computation of streamflow: Volume 1. Measurement of stage and discharge, 1982. Washington, DC, USA: US Government Printing Office, Geological Survey Water-Supply Paper 2175. $18 \mathrm{p}$.

SANDINE, M. E. 1974. Natural and simulated insect-substrate relationships in Idaho batholith stream [thesis]. Moscow, ID, USA: University of Idaho. 45 p. 
Santos, R., L. Ribelro, and A. C. Dill. 2005. The use of multivariate statistical analysis to evaluate spatial and temporal water contamination in Germunde coal mine (Portugal). Fourth Inter-Celtic Colloquium on Hydrology and Management of Water Resources; 11-14 July 2005; Guimarães, Portugal. Lisbon, Portugal: University of Algarve. 9 p.

[SAS] Statistical Analysis Software Institute. 2002. SAS/STAT user's guide. Release 8.2. Cary, NC, USA: SAS. 352 p.

Shrestha, S., and F. KazAma. 2006. Assessment of surface water quality using multivariate statistical techniques: a case study of the Fuji river basin, Japan. Environmental Modeling and Software 22:464-475.

Singh, K. P., A. MaliK, And S. SinHA. 2005. Water quality assessment and apportionment of pollution sources of Gomti river (India) using multivariate statistical techniques-a case study. Analytica Chimica Acta 538:355-374.

SkINNER, Q. D. 2003. Rangeland monitoring: water quality and riparian systems. Arid Land Research and Management 17:407-428.

[SPSS] Statistical Package for the Social Sciences [computer program]. 2005. Version 14.0. Chicago, IL, USA: SPSS Inc.

St-Hilaire, A., G. Brun, S. C. Courtenay, T. B. M. J. Ouarda, A. D. Doghen, and B. BoвÉE. 2004. Multivariate analysis of water quality in the Richibucto Drainage basin (New Brunswick, Canada). Journal of the American Water Resources Association 40:691-703.

Stanley, E. H., S. G. Fisher, and N. B. Grimm. 1997. Ecosystem expansion and contraction in streams-desert streams vary in both space and time and fluctuate dramatically in size. BioScience 47:427-435.

Steldtmann, J. R. 1993. The cretaceous foreland basin and its sedimentary record. In: A. W. Snoke, J. R. Steidtmann, and S. M. Roberts [EDS.]. Geology of Wyoming: geological survey of Wyoming memoir 5. Laramie, WY, USA: Geological Survey of Wyoming. p. 250-271.

Swain, B. W. 1957. Fort union formation, west flank of the Sierra Madre, Carbon County, Wyoming [thesis]. Laramie, WY, USA: University of Wyoming. $132 \mathrm{p}$.

Thompson, B. 1984. Canonical correlation analysis uses and interpretation. Sage University paper series on quantitative application in the social sciences, 07047. Beverly Hills, CA, USA: Sage Publications. $71 \mathrm{p}$.

[USDA] United States Department of Agriculture. 1985. Agricultural statistics. Washington, DC, USA: US Government Printing Office. 494 p.

[USDA] United States Department of Agriculture. 1990. Agricultural Conservation Partnership water quality special project proposal within the existing Muddy Creek demonstration area, Carbon County, Wyoming. Casper, WY, USA:
Agricultural Stabilization and Conservation Service, Cooperative Extension Service, and Soil Conservation Service; and Laramie, WY, USA: University of Wyoming. $26 \mathrm{p}$.

Vanotte, R. L., G. W. Minshall, K. W. Cummins, J. R. Sedell, and C. E. Cushing. 1980. The river continuum concept. Canadian Journal of Fisheries and Aquatic Sciences 37:130-137.

Vitousek, P. M. 1977. The regulation of element concentrations in mountain streams in the northeastern United States. Ecological Monographs 47:65-87.

Walling, D. E. 1984. Dissolved loads and their measurements. In: R. F. Hadley and D. E. Walling [EDS.]. Erosion and sediment yield: some methods of measurement and modeling. Norwich, United Kingdom: Geo Books, Regency House. p. 111-177.

[WDEQ] Wyoming Department of Environmental Quality. 2006. Wyoming's 2006 305(b) state water quality assessment report and 2006 303(d) list of waters requiring TMDLs. Available at: http://deq.state.wy.us/wqd/watershed/downloads/ 305b/2006/2006\%20303d.pdf. Accessed 15 June 2007.

[WDEQ/WQD] Wyoming Department of Environmental Quality/Water Quality Division. 2004. Manual of standard operating procedures for sample collection and analysis. Cheyenne, WY, USA: WDEQ/WQD. 375 p.

WEIGEL, B. M. 2003. Development of stream macroinvertebrate models that predict watershed and local stressors in Wisconsin. Journal of the American Benthological Society 22:123-142.

Western Regional Climate Center. 2008. Baggs 480484, Wyoming, monthly total precipitation. Available at: http://www.wrcc.dri.edu/cgi-bin/cliMAIN.pl?wybagg. Accessed 24 January 2008.

Winget, R. N., and F. A. Mangum. 1979. Biotic condition index: integrated biological, physical, and chemical stream parameters for management. Ogden, UT, USA: US Department of Agriculture, Forest Service, Intermountain Region. $51 \mathrm{p}$.

Wood, P. J., M. D. Agnew, and G. E. Petts. 2000. Flow variations and macroinvertebrate community responses in a small groundwater-dominated stream in southeast England. Hydrological Processes 14:3133-3147.

ZHou, F., Y. LIU, AND H. Guo. 2007. Application of multivariate statistical methods to water quality assessment of the watercourses in northwestern new territories, Hong Kong. Environmental Monitoring and Assessment 132:1-13.

ZoË, S. D., B. W. Alexander, and R. G. Death. 2007. A review of the consequences of decreased flow for instream habitat and macroinvertebrates. Journal of the North American Benthological Society 26:401-415. 